\title{
INNOVATOR INDEX FOR DURABLE GOODS IN TIRUVARUR DISTRICT
}

\author{
T. Padmaja \\ Bharathi Women's College (Autonomous), Department of Commerce, No.1, Prakasam Salai, \\ George Town, Chennai Tamilnadu, India.
}

\begin{abstract}
White and Brown consumer durables have similar features and are commoditized in Indian market. In this scenario, one of the key strategies being adopted by major consumer durable companies is introducing innovative features to their durable's goods brand. However, innovation comes with a price, as consumers might not be familiar with new innovative features and may hesitate to the buy the durables with arcane features. This is where study of innovator adaption becomes essential. In this study, the propensity of consumers for buying durables with new and innovative features is determined for Tiruvarur district. Based on the analysis, innovator index for Tiruvarur district is derived. The higher the index, the higher is the probability that consumers will buy new and innovative durables. Such an index helps in brand marketing and position new products. It helps consumer durable companies to test new and innovative features in consumer durables by launching such products in areas of high innovator index. The study also derives the probability distribution of components of Innovator Index - Awareness, Interest, Desire and Capability. This helps the durable goods companies to structure their product and marketing mix based on the probability values of the components of Innovator Index.
\end{abstract}

Keywords: Innovator Index, Consumer Durables, Probability Distribution Function, Product launch

Cite this article: T. Padmaja, Innovator Index for Durable Goods in Tiruvarur District, Journal of Management (JOM),6(1), 2019, pp: 97-106

http://www.iaeme.com/JOM/issues.asp?JType=JOM\&VType=6\&IType=1

\section{INTRODUCTION}

Indian consumer durables market is attracting marketers from across the world primarily due to favorable population composition and increasing disposable incomes. According to India Brand Equity Foundation, which is an initiative of the Ministry of Commerce \& Industry, Indian appliance and consumer electronics market reached Rs 2.05 trillion (US\$ 31.48 billion) in 2017. Every durable goods company wants a share of this huge market pie. However, the market is flooded with durable goods which are not very distinctive. Almost all brands of both white and brown consumer durables have similar features and are commoditized. In this scenario of 
indistinguishable brands, one of the key strategies being adopted by major consumer durable companies is introducing innovative features to their durable's goods brand. However, innovation comes with a price as consumers might not be familiar with new innovative features and may hesitate to the buy the durables with arcane features. This is where study of innovator adaption becomes essential. This study is part of larger research on consumers durables and non-durables in Tiruvarur district of Tamilnadu, India. In this part of study, the propensity of consumers for buying durables with new and innovative features is studied and anaysed. Based on the analysis, innovator index for Tiruvarur district is derived. The higher the index, the higher is the probability that consumers will buy new and innovative durables. Such an index helps in brand marketing and position new products. It helps consumer durable companies to test new and innovative features in consumer durables by launching such products in areas of high innovative index. All new features can be test marketed in areas with high Innovator index before national launch. The study also derives the probability distribution of components of Innovator Index - Awareness, Interest, Desire and Capability. This helps the durable goods companies to structure their product and marketing mix based on the probability values of the components of Innovator Index.

\section{LITERATURE REVIEW}

In 2019, Smith, David \& Langlois, Edgar \& Lazau, Marius in their article "An empirical investigation of the adoption behavior of technological service innovation. An empirical investigation of the adoption behavior of technological service innovation", examine the adoption propensity of 379 randomly selected firms. Inquiry is made regarding organizational and managerial determinants of these firms. They examine which behavioral determinants are the most effective in differentiating between the adopters and non-adopters of technology service innovations

Rossetti, G., Milli, L., Giannotti, F., \& Pedreschi, D. in their 2017 research titled "Forecasting success via early adoptions analysis: A data-driven study" provide a data-driven account of the existence of a special niche among early adopters who are consumers who like to try out innovative, new features in products. They devise a predictive analytical process which achieves high accuracy in the early-stage prediction of successful innovations which can be used to support marketing strategies and product placement.

Cisternas, Eduardo in 2016 paper titled "Exploring individual differences in early adoption behavior of innovation" assesses personality traits and basic values as a predictor of early adoption behavior through a Mixed-method that includes a semi-structure interview and a selfreport instrument. The main objective of the paper is to identify early adopter of Chilean Startups innovation project and to characterize them regarding personality traits and basic values for the purpose of exploring a relationship of the variables with intentions of early adoption behavior of innovations.

Lynn, Theodore \& Muzellec, Laurent \& Caemmerer, Barbara \& Turley, Darach \& Wuerdinger, Bettina. In 2014 in their research titled "Early Adopters of Twitter and Google+: Validation of a Theoretical Model of Early Adopter Personality and Social Network Site Influence" seek to identify and describe the personality traits and level of social networking sites influence of early adopters of Twitter and Google.

\section{METHODOLOGY}

\subsection{Sample and Sampling Method}

Seven Municipalities under Tiruvarur were selected by convenient sampling method. The municipalities include Thiruvarur, Thiruthuraipoondi, Koothanallur, Nannilam, 
Needamangalam, Kudavasal and Valangaiman. 50 participants from durable shops in town centers of each municipalities were randomly selected and structured questionnaire were administered to them. The total sample size was 350 .

\subsection{Procedure}

In order to determine the innovation index, the respondents' Awareness of innovative features, Interest in the durables, Desire to buy the durable with innovative features and Capability to buy the product was rated on 10-point Likert scale. Score of 1 represented the lowest Awareness, Interest, Desire and Capability while score 10 represented highest Awareness, Interest, Desire and Capability. The ratings for each parameter were averaged. Next the four parameters - Awareness, Interest, Desire and Capability - were aggregated using displaced ideal method.

\subsection{Durables examined}

Three white goods - Refrigerator, Air conditioners and Microwave oven and two brown goods - Smart Television and laptops were selected for study and rating.

\subsection{Aggregation using the displaced ideal method}

The second step after rating calculations is aggregation of the four parameters (Awareness, Interest, Desire and Capability). The four parameters represent a four-dimensional space with 0 as the minimum value and 100 as the maximum (ideal) for each dimension. The Displaced Ideal method is used since it is based the on the concept that the better system should have less distance from ideal. Displaced Ideal method also satisfies the axioms of Proximity, Uniformity and Signaling. The Euclidean Distance Method is used to calculate the distance between any two points in an n-dimensional space. Hence the value of Innovator index of durables in Tiruvarur distrct of Tamil Nadu is measured using the Euclidean Distance formula:

Innovator Index

$=100-\sqrt{\frac{(100-\text { Awareness })^{2}+(100-\text { Interest })^{2}+(100-\text { Desire })^{2}+(100-\text { Capability })^{2}}{4}}$

\subsection{Probability Distribution Analysis of components of Innovator Index}

In order to understand the propensity of consumers to buy innovative durable goods better, the $50 \%$ probability value of Awareness, Interest, Desire and Action for the top three municipalities are analysed.

To understand the type of distribution, Probability Distribution Analysis is carried out. Analysing the Probability distribution and creating a Probability Density Function based on the data distribution is important to know the value of components of Innovator Index

The probability distribution is calculated using Goodness of Fit. To find the best Goodness of Fit, Kolmogorov Smirnov, Anderson Darling and Chi-Squared test are carried out.

\subsection{Kolmogorov-Smirnov Test}

This test is used to decide if a sample comes from a hypothesized continuous distribution. It is based on the empirical cumulative distribution function (ECDF). Assume that we have a random sample $\mathrm{x} 1$, $\mathrm{xn}$ from some distribution with $\mathrm{CDF} F(\mathrm{x})$. The empirical CDF is denoted by

$$
F_{n}(x)=\frac{1}{n} \cdot[\text { Number of observations } \leq x]
$$




\subsection{Definition}

The Kolmogorov-Smirnov statistic (D) is based on the largest vertical difference between the theoretical and the empirical cumulative distribution function:

$$
D=\max _{1 \leq i \leq n}\left(F\left(x_{i}\right)-\frac{i-1}{n}, \frac{i}{n}-F\left(x_{i}\right)\right)
$$

In order to determine whether the data follows a probability distribution, P-value is calculated based on the test statistic which denotes the threshold value of the significance level.

\subsection{Anderson-Darling Test}

The Anderson-Darling procedure is a general test to compare the fit of an observed cumulative distribution function to an expected cumulative distribution function. This test gives more weight to the tails than the Kolmogorov-Smirnov test.

\subsection{Definition}

The Anderson-Darling statistic $\left(\mathrm{A}^{2}\right)$ is defined as

$$
A^{2}=-n-\frac{1}{n} \sum_{i=1}^{n}(2 i-1) \cdot\left[\ln F\left(X_{i}\right)+\ln \left(1-F\left(X_{n-i+1}\right)\right)\right]
$$

\subsection{Chi-Square test}

In the probability distribution calculation, the test is used to determine if a sample comes from a population with a specific distribution. This test is applied to binned data.

Although there is no optimal choice for the number of bins (k), there are several formulas which can be used to calculate this number based on the sample size $(\mathrm{N})$. The formula used for binning is:

$$
k=1+\log _{2} N
$$

When the probability distribution goodness of fit ranking differs, Kolmogorov Smirnov statistics is given preference over other methods.

\section{DATA ANALYSIS}

The analysis of Awareness, Interest, Desire and Capability of 350 respondents across seven municipalities of Tiruvarur District was completed and the results are tabulated below:

Table 1 Innovator index Parameter ratings in Tiruvarur District

\begin{tabular}{|c|c|c|c|c|c|c|c|}
\hline $\begin{array}{c}\text { Municipal } \\
\text { ities }\end{array}$ & $\begin{array}{c}\text { Thiruva } \\
\text { rur }\end{array}$ & $\begin{array}{c}\text { Thiruthuraip } \\
\text { oondi }\end{array}$ & $\begin{array}{c}\text { Koothan } \\
\text { allur }\end{array}$ & $\begin{array}{c}\text { Nannil } \\
\text { am }\end{array}$ & $\begin{array}{c}\text { Needamang } \\
\text { alam }\end{array}$ & $\begin{array}{c}\text { Kudav } \\
\text { asal }\end{array}$ & $\begin{array}{c}\text { Valangai } \\
\text { man }\end{array}$ \\
\hline Awareness & 6.84 & 5.82 & 4.72 & 4.36 & 3.58 & 2.8 & 2.74 \\
\hline Interest & 6.92 & 5.9 & 4.9 & 4.04 & 3.4 & 3 & 2.66 \\
\hline Desire & 7 & 6.22 & 5.34 & 4.14 & 3.72 & 3.2 & 2.6 \\
\hline Capability & 7.12 & 6.06 & 5.24 & 3.92 & 3.1 & 2.72 & 2.72 \\
\hline $\begin{array}{c}\text { Innovator } \\
\text { Index }\end{array}$ & 6.97 & 6.00 & 5.05 & 4.11 & 3.45 & 2.93 & 2.68 \\
\hline
\end{tabular}

It can be determined from the data in table 1 that the Innovator index is highest for Thiruvarur (Innovator Index score : 6.97), followed by Thiruthuraipoondi (Innovator Index score :6.00 ), Koothanallur (Innovator Index score :5.05 ), Nannilam (Innovator Index score 
:4.11 ), Needamangalam (Innovator Index score :3.45), Kudavasal (Innovator Index score :2.93 ) and Valangaiman (Innovator Index score :2.68 ). Thus, companies will be better off launcghing and test marketing new and innovative durable goods and home appliances in Thiruvarur municipality than Valngaiman municipality.

The radar chart depicting the Innovator Index of municipalities of Tiruvarur district is depicted in the Figure 1 below.

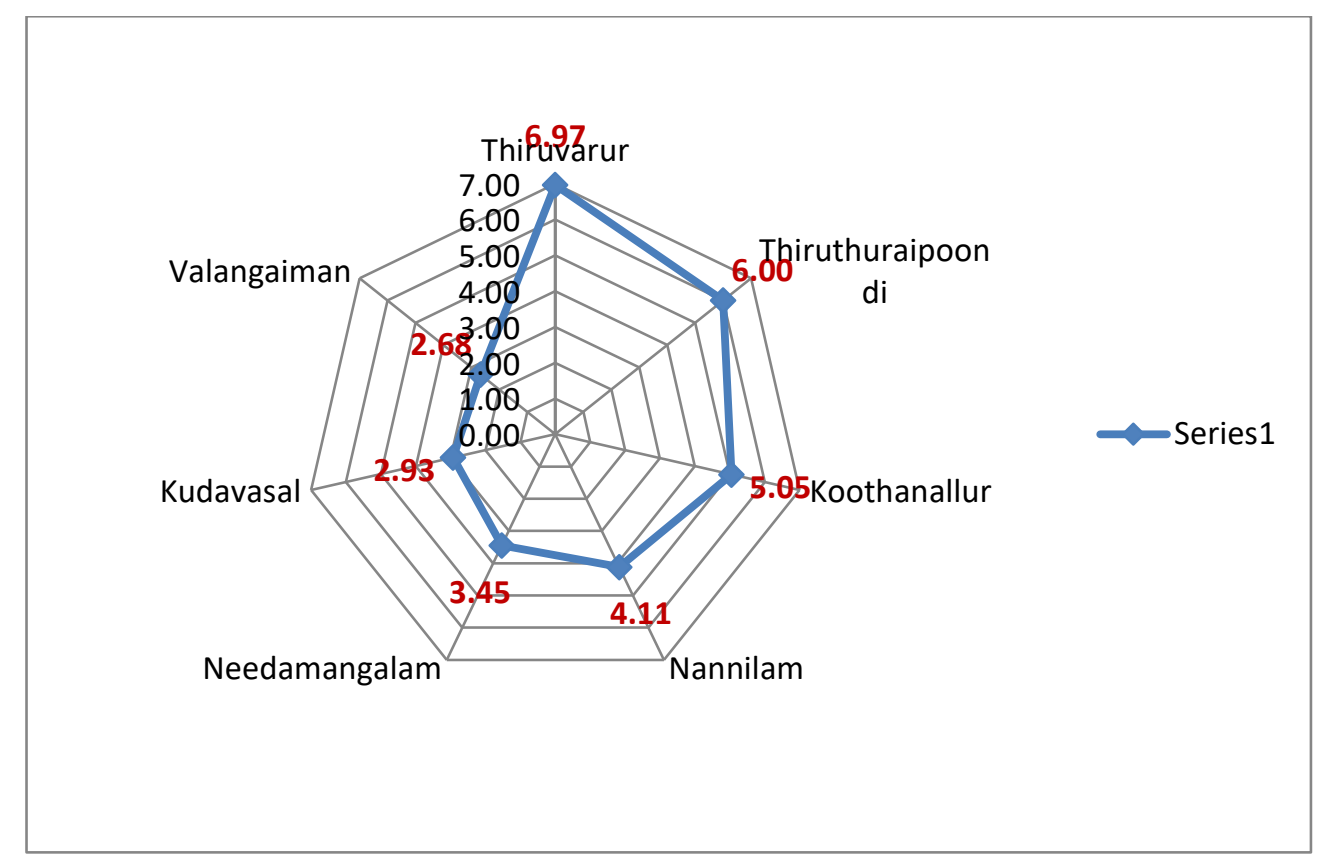

Figure 1 Innovator Index of Tiruvarur District

The above figure 1 depicts the Innovative Index of Tiruvarur District. The higher the value of the index, higher is the consumers propensity for innovative and new durable goods. Thus, consumers of durable goods in Thiruvarur are 2.60 times more inclined to accept innovative and new features durables goods than consumers in Kudavasal.

In order to understand the propensity of consumers to buy innovative durable goods better, the $50 \%$ probability value of Awareness, Interest, Desire and Action for the top three municipalities are analysed.

\subsection{Probability Distribution Analysis of Awareness}

To understand the type of distribution of Awareness, Probability Distribution Analysis was carried out. Analysing the Probability distribution and creating a Probability Density Function based on the data distribution is important to know the value of Awareness and to know the probability of any value of Awareness.

The probability distribution of Awareness was calculated using Goodness of Fit. To find the best Goodness of Fit, Kolmogorov Smirnov, Anderson Darling and Chi-Squared test are carried out.

The three Goodness of fit test is carried out to determine the Probability Distribution of Awareness. The Probability Distribution of Awareness is shown below 
Table 2 Goodness of fit Summary - Probability Distribution of Awareness

\begin{tabular}{|c|c|c|c|c|c|c|}
\hline \multirow{2}{*}{ Distribution } & \multicolumn{2}{|c|}{$\begin{array}{c}\text { Kolmogorov } \\
\text { Smirnov }\end{array}$} & \multicolumn{2}{c|}{$\begin{array}{c}\text { Anderson } \\
\text { Darling }\end{array}$} & \multicolumn{2}{c|}{ Chi-Squared } \\
\cline { 2 - 7 } & Statistic & Rank & Statistic & Rank & Statistic & Rank \\
\hline Uniform & 0.14343 & 1 & 1.4954 & 1 & 15.502 & 46 \\
\hline Error & 0.14349 & 2 & 1.4958 & 2 & 15.493 & 45 \\
\hline Johnson SB & 0.15111 & 3 & 1.5747 & 5 & 14.529 & 42 \\
\hline
\end{tabular}

The above Table shows the goodness of fit parameters of Awareness. The Awareness data is fitted on various probability distribution and the probability distribution fit is ranked. When the ranking data differ, Kolmogorov Smirnov statistics is given preference. It can be seen that Uniform probability distribution is ranked first. It can be concluded that Awareness follows Uniform probability distribution and the values can be predicted based on that probability distribution.

Based on the probability distribution, there is a $50 \%$ probability that Awareness value of Thiruvarur municipality is below 6.84 .

The graph of Probability Density Function of Awareness in Thiruvarur municipality is depicted below. The probability values and the Awareness can be correlated based on the graph below. The X-Axis represents the Awareness score and the Y-Axis depicts the probabilities.

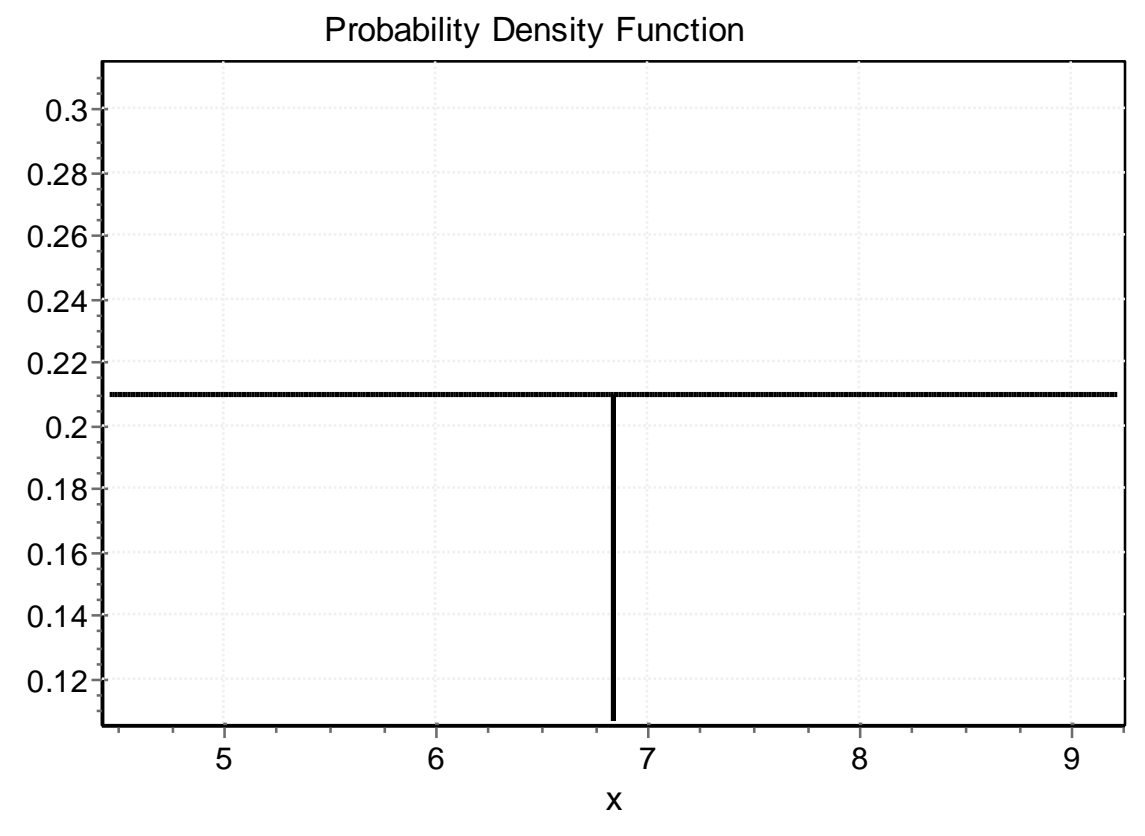

Uniform $(4.4574 ; 9.2226)$

Figure 2 Probability Density Function of Awareness

Similarly, the Probability distribution of Awareness for Thiruthuraipoondi and Koothanallur is determined. The results of the analysis are depicted below: 
Mrs.T.Padmaja

Table 3 Awareness Probability Values of top three Municipalities in Thiruthuraipoondi District

\begin{tabular}{|c|c|c|c|c|c|c|c|c|}
\hline \multirow{2}{*}{$\begin{array}{c}\text { Municipalitie } \\
\text { s }\end{array}$} & \multirow{2}{*}{$\begin{array}{c}\text { Distributi } \\
\text { on }\end{array}$} & \multicolumn{2}{|c|}{$\begin{array}{c}\text { Kolmogorov } \\
\text { Smirnov }\end{array}$} & \multicolumn{2}{|c|}{$\begin{array}{c}\text { Anderson } \\
\text { Darling }\end{array}$} & \multicolumn{2}{c|}{ Chi-Squared } & \multicolumn{2}{|c|}{$\begin{array}{c}\mathbf{5 0} \% \\
\text { probability }\end{array}$} \\
\cline { 3 - 9 } & & $\begin{array}{c}\text { Statist } \\
\text { ic }\end{array}$ & $\begin{array}{c}\text { Ran } \\
\mathbf{k}\end{array}$ & $\begin{array}{c}\text { Statist } \\
\text { ic }\end{array}$ & $\begin{array}{c}\text { Ran } \\
\mathbf{k}\end{array}$ & $\begin{array}{c}\text { Statist } \\
\text { ic }\end{array}$ & $\begin{array}{c}\text { Ran } \\
\mathbf{k}\end{array}$ & \\
\hline Thiruvarur & Uniform & $\begin{array}{c}0.1434 \\
3\end{array}$ & 1 & $\begin{array}{c}1.495 \\
4\end{array}$ & 1 & $\begin{array}{c}15.50 \\
2\end{array}$ & 46 & $\mathbf{6 . 8 4}$ \\
\hline $\begin{array}{c}\text { Thiruthuraipo } \\
\text { ondi }\end{array}$ & Weibull & $\begin{array}{c}0.1467 \\
1\end{array}$ & 1 & $\begin{array}{c}1.720 \\
3\end{array}$ & 4 & $\begin{array}{c}1.290 \\
7\end{array}$ & 6 & $\mathbf{5 . 9 0 4 9}$ \\
\hline Koothanallur & $\begin{array}{c}\text { Johnson S } \\
\text { B }\end{array}$ & $\begin{array}{c}0.1511 \\
1\end{array}$ & 3 & $\begin{array}{c}1.574 \\
7\end{array}$ & 5 & $\begin{array}{c}14.52 \\
9\end{array}$ & 42 & $\mathbf{4 . 7 0 3 8}$ \\
\hline
\end{tabular}

Based on data in table 3, the best probability distribution for Awareness for Thiruvarur municipality is Uniform probability distribution, for Thiruthuraipoondi municipality is Weibull and for Koothanallur municipality is Johnson SB distributions. There is a $50 \%$ probability that Awareness value of Thiruthuraipoondi and Koothanallur municipalities are below 5.9049 and 4.7038 respectively.

\subsection{Probability Distribution Analysis of Interest}

The Probability distribution of Desire for Thiruvarur, Thiruthuraipoondi and Koothanallur are determined. The results of the analysis are depicted below:

Table 4 Interest Probability Values of top three Municipalities in Tiruvarur District

\begin{tabular}{|c|c|c|c|c|c|c|c|c|}
\hline Municipalities & $\begin{array}{c}\text { Distributi } \\
\text { on }\end{array}$ & \multicolumn{2}{|c|}{ Kolmogorov } & \multicolumn{2}{|c|}{ Anderson } & \multicolumn{2}{c|}{$\begin{array}{c}\text { Chi- } \\
\text { Squared }\end{array}$} & \\
\hline & & $\begin{array}{c}\text { Smirn } \\
\text { ov }\end{array}$ & & $\begin{array}{c}\text { Darlin } \\
\mathrm{g}\end{array}$ & & & & \\
\hline & $\begin{array}{c}\text { Statisti } \\
\mathrm{c}\end{array}$ & $\begin{array}{c}\text { Ran } \\
\mathrm{k}\end{array}$ & $\begin{array}{c}\text { Statist } \\
\text { ic }\end{array}$ & $\begin{array}{c}\text { Ran } \\
\mathrm{k}\end{array}$ & $\begin{array}{c}\text { Statist } \\
\text { ic }\end{array}$ & $\begin{array}{c}\text { Ran } \\
\mathrm{k}\end{array}$ & $\begin{array}{c}50 \% \\
\text { probability }\end{array}$ \\
\hline Thiruvarur & $\begin{array}{c}\text { Johnson S } \\
\mathrm{B}\end{array}$ & $\begin{array}{c}0.1441 \\
3\end{array}$ & 1 & $\begin{array}{c}1.730 \\
9\end{array}$ & 1 & $\begin{array}{c}2.657 \\
6\end{array}$ & 5 & $\mathbf{6 . 8 4 1 5}$ \\
\hline $\begin{array}{c}\text { Thiruthuraipoo } \\
\text { ndi }\end{array}$ & Pearson 6 & 0.1309 & 1 & $\begin{array}{c}1.547 \\
5\end{array}$ & 7 & $\begin{array}{c}15.57 \\
2\end{array}$ & 51 & $\mathbf{5 . 8 2 7 5}$ \\
\hline Koothanallur & Wakeby & $\begin{array}{c}0.1206 \\
6\end{array}$ & 1 & $\begin{array}{c}1.319 \\
7\end{array}$ & 4 & $\begin{array}{c}7.733 \\
5\end{array}$ & 38 & $\mathbf{4 . 8 7 9 8}$ \\
\hline
\end{tabular}

Data from table 4 shows that the best probability distribution for Interest for Thiruvarur municipality is Johnson SB, for Thiruthuraipoondi municipality is Pearson 6 and for Koothanallur municipality is Wakeby, distributions. There is a $50 \%$ probability that Interest value of Thiruvarur, Thiruthuraipoondi and Koothanallur municipalities are below 6.8415, $\mathbf{5 . 8 2 7 5}$ and 4.8798 respectively.

\subsection{Probability Distribution Analysis of Desire}

The Probability distribution of Desire for Thiruvarur, Thiruthuraipoondi and Koothanallur are determined. The results of the analysis are depicted below: 
Table 5 Desire Probability Values of top three Municipalities in Tiruvarur District

\begin{tabular}{|c|c|c|c|c|c|c|c|c|}
\hline \multirow[t]{2}{*}{ Municipalities } & \multirow{2}{*}{$\begin{array}{c}\text { Distributio } \\
\text { n }\end{array}$} & \multicolumn{2}{|c|}{ Kolmogorov } & \multicolumn{2}{|c|}{ Anderson } & \multicolumn{2}{|c|}{ Chi-Squared } & \\
\hline & & $\begin{array}{c}\text { Smirno } \\
\mathrm{v}\end{array}$ & & $\begin{array}{l}\text { Darlin } \\
\mathrm{g}\end{array}$ & & & & \\
\hline & & $\begin{array}{l}\text { Statisti } \\
\mathrm{c}\end{array}$ & $\begin{array}{c}\text { Ran } \\
\mathrm{k}\end{array}$ & $\begin{array}{l}\text { Statisti } \\
\mathrm{c}\end{array}$ & $\begin{array}{c}\text { Ran } \\
\mathrm{k}\end{array}$ & $\begin{array}{c}\text { Statisti } \\
\mathrm{c}\end{array}$ & $\begin{array}{c}\text { Ran } \\
\mathrm{k}\end{array}$ & $\begin{array}{c}50 \% \\
\text { probability }\end{array}$ \\
\hline Thiruvarur & Weibull & 0.1464 & 1 & 1.7911 & 4 & 3.8837 & 29 & 7.0562 \\
\hline $\begin{array}{c}\text { Thiruthuraipoon } \\
\text { di }\end{array}$ & $\begin{array}{c}\text { Dagum (4P } \\
\text { ) }\end{array}$ & $\begin{array}{c}0.1509 \\
6 \\
\end{array}$ & 1 & 1.8314 & 6 & 5.1826 & 20 & 6.5741 \\
\hline Koothanallur & Wakeby & $\begin{array}{c}0.1563 \\
9\end{array}$ & 1 & 1.6125 & 2 & 10.357 & 44 & 5.6091 \\
\hline
\end{tabular}

Table 5 indicates that the best probability distribution for Desire for Thiruvarur municipality is Weibull for Thiruthuraipoondi municipality is Dagum (4P) and for Koothanallur municipality is Wakeby. There is a $50 \%$ probability that Desire value of Thiruvarur, Thiruthuraipoondi and Koothanallur municipalities are below 7.0562, 6.5741 and 5.6091, respectively.

\subsection{Probability Distribution Analysis of Capacity}

The Probability distribution of capacity for Thiruvarur, Thiruthuraipoondi and Koothanallur are determined. The results of the analysis are depicted below:

Table 6 Capacity Probability Values of top three Municipalities in Tiruvarur District

\begin{tabular}{|c|c|c|c|c|c|c|c|c|}
\hline Municipalities & $\begin{array}{c}\text { Distributi } \\
\text { on }\end{array}$ & \multicolumn{2}{|c|}{ Kolmogorov } & \multicolumn{2}{|c|}{ Anderson } & \multicolumn{2}{c|}{$\begin{array}{c}\text { Chi- } \\
\text { Squared }\end{array}$} & \\
\hline & & $\begin{array}{c}\text { Smirn } \\
\text { ov }\end{array}$ & & $\begin{array}{c}\text { Darlin } \\
\mathrm{g}\end{array}$ & & & & \\
\hline & $\begin{array}{c}\text { Statisti } \\
\mathrm{c}\end{array}$ & $\begin{array}{c}\text { Ran } \\
\mathrm{k}\end{array}$ & $\begin{array}{c}\text { Statist } \\
\text { ic }\end{array}$ & $\begin{array}{c}\text { Ran } \\
\mathrm{k}\end{array}$ & $\begin{array}{c}\text { Statist } \\
\text { ic }\end{array}$ & $\begin{array}{c}\text { Ran } \\
\mathrm{k}\end{array}$ & $\begin{array}{c}50 \% \\
\text { probability }\end{array}$ \\
\hline $\begin{array}{c}\text { Thiruvarur } \\
\text { Thiruthuraipoo } \\
\text { ndi }\end{array}$ & Uniform & $\begin{array}{c}0.1248 \\
9\end{array}$ & 1 & $\begin{array}{c}1.414 \\
6\end{array}$ & 1 & $\begin{array}{c}8.618 \\
9\end{array}$ & 43 & $\mathbf{7 . 1 2}$ \\
\hline $\begin{array}{c}\text { Gen. Paret } \\
\text { Koothanallur }\end{array}$ & $\begin{array}{c}0.1262 \\
2\end{array}$ & 1 & 1.335 & 1 & $\begin{array}{c}3.496 \\
7\end{array}$ & 8 & $\mathbf{6 . 1 0 2 1}$ \\
\hline
\end{tabular}

It can be noted from table 6 data that the best probability distribution for Desire for Thiruvarur municipality is Uniform, for Thiruthuraipoondi municipality is Gen. Pareto and for Koothanallur municipality is Uniform. There is a $50 \%$ probability that Capacity value of Thiruvarur, Thiruthuraipoondi and Koothanallur municipalities are below 7.12, 6.1021 and $\mathbf{5 . 2 4}$ respectively.

\section{FINDINGS AND DISCUSSION}

The Innovator index is highest for Thiruvarur (Innovator Index score: 6.97), followed by Thiruthuraipoondi (Innovator Index score :6.00), Koothanallur (Innovator Index score :5.05), Nannilam (Innovator Index score :4.11), Needamangalam (Innovator Index score :3.45), Kudavasal (Innovator Index score :2.93) and Valangaiman (Innovator Index score :2.68). 
Thus, companies will be better off launching and test marketing new and innovative durable goods and home appliances in Thiruvarur municipality than Valngaiman municipality. The consumers of durable goods in Thiruvarur are 2.60 times more inclined to accept innovative and new features durables goods than consumers in Kudavasal.

The component wise analysis indicates that as far as Awareness about new features in consumers durables is concerned, Uniform probability distribution is ranked first for Thiruvarur municipality and there is a $50 \%$ probability that Awareness value of Thiruvarur municipality is below 6.84. For Thiruthuraipoondi municipality best fir probability distribution is Weibull and for Koothanallur municipality it is Johnson SB distribution. There is a $50 \%$ probability that Awareness value of Thiruthuraipoondi and Koothanallur municipalities are below 5.9049 and 4.7038 respectively. It was also noted that the best probability distribution for Interest for Thiruvarur municipality is Johnson SB, for Thiruthuraipoondi municipality is Pearson 6 and for Koothanallur municipality is Wakeby distribution. There is a $50 \%$ probability that Interest value of Thiruvarur, Thiruthuraipoondi and Koothanallur municipalities are below 6.8415, 5.8275 and 4.8798 respectively. Similarly the best probability distribution for Desire for Thiruvarur municipality is Weibull for Thiruthuraipoondi municipality is Dagum (4P) and for Koothanallur municipality is Wakeby. There is a $50 \%$ probability that Desire value of Thiruvarur, Thiruthuraipoondi and Koothanallur municipalities are below 7.0562, 6.5741 and 5.6091, respectively. It was also found that the best probability distribution for Desire for Thiruvarur municipality is Uniform, for Thiruthuraipoondi municipality is Gen. Pareto, and for Koothanallur municipality is Uniform probability distribution. There is a $50 \%$ probability that Capacity value of Thiruvarur, Thiruthuraipoondi and Koothanallur municipalities are below $7.12,6.1021$ and 5.24 respectively. The durable companies thus have unprecedented data distribution as far as Innovative durables goods marketing is considered. The companies' marketing and production department can form cross functional team to get desired level of innovation in their durables to suit the market they are trying to capture. Similar study can be done on all India basis to form Innovator Index for all major cities which will help durable goods companies to shine in new markets

\section{CONCLUSION}

The research highlights a novel approach to marketing, position and test launch of durable goods with new features. It shows a new methodology to tap the early and late innovator consumers for faster adaption of durable goods. The combination of Innovator Index and Probability Distribution Functions of its components can be considered as new arsenal in marketing strategy of durables companies. Expanding this research to cover all India markets will help companies immensely in marketing, positioning and launching of innovative durables and home appliances with ease and assured success.

\section{REFERENCES}

[1] Smith, David \& Langlois, Edgar \& Lazau, Marius, An empirical investigation of the adoption behavior of technological service innovation., 2019

[2] Rossetti, G., Milli, L., Giannotti, F., \& Pedreschi, D. (2017). Forecasting success via early adoptions analysis: A data-driven study. PloS one, 12(12), 2017,e0189096. doi: 10.1371/journal.pone.0189096

[3] Cisternas, Eduardo, Exploring individual differences in early adoption behavior of innovation. 10.13140/RG.2.2.19596.51848/1., 2016 
[4] Dr. R. Khader Mohideen and P. Saravanan. A Study on Impact of Television Advertisement on Purchase Decisions of Consumer Durable Goods in Tiruchirappalli District. International Journal of Management, 7(2), 2016, pp. 484-488.

[5] http://www.iaeme.com/ijm/index.asp

[6] Lynn, Theodore \& Muzellec, Laurent \& Caemmerer, Barbara \& Turley, Darach \& Wuerdinger, Bettina, Early Adopters of Twitter and Google+: Validation of a Theoretical Model of Early Adopter Personality and Social Network Site Influence, 2014 